\title{
УДК 332.12:504.03
}

\section{ИСПОЛЬЗОВАНИЕ КЛЮЧЕВЫХ ПОКАЗАТЕЛЕЙ В ОЦЕНКЕ РАЗВИТИЯ МОНОГОРОДОВ НА РЕГИОНАЛЬНОМ УРОВНЕ}

\author{
Людмила Н. Медведева ${ }^{1,}$, Михаил К. Старовойтов ${ }^{1}$, Елена В. Гончарова ${ }^{1}$, Юлия И. Гущцина
}

${ }^{1}$ Волжский политехнический институт (филиал) Волгоградского государственного технического университета, Россия, 404121, г. Волжский, ул. Энгельса, $42 a$

@ milena.medvedeva2012@yandex.ru

Поступила в редакциию 19.02.2018. Принята к печати 12.03.2018.

Ключевые слова: моногорода, инвестиции, комплексные инвестиционные планы по модернизации моногородов, эффективность бюджетных средств, экономика города, эконом-математическая модель.
Аннотация: Дальнейшее развитие моногородов, экономика которых полностью зависела от одного-двух градообразующих предприятий и от научно-исследовательских институтов и конструкторских бюро, расположенных здесь, является чрезвычайно актуальным. Правительственной комиссией были приняты комплексные инвестиционные планы по модернизации моногородов, даны разрешения на создание на их базе «свободных экономических зон» и «территорий опережающего развития», что в конечном итоге должно повлиять на их экономический рост. Проведенный анализ показал, что основное внимание в стратегии развития моногородов отводится развитию местной промышленности и малого бизнеса, связанному с оборонным комплексом, сельским хозяйством; местными властями предлагаются проекты строительства свиноферм, молоко-, мясо, масло-, рыбоперерабатывающих производств, открытие производств в сфере стройиндустрии. Однако вопрос эффективного вложения бюджетных средств и инвестиций продолжается оставаться весьма обсуждаемым в экономической науке. Предлагаемые в статье ключевые показатели развития моногородов, эконом-математические модели распределения инвестиционных потоков, позволяют спрогнозировать векторы их развития на дальнюю перспективу.

Для цитирования: Медведева Л. Н., Старовойтов М. К., Гончарова Е. В., Гущина Ю. И. Использование ключевых показателей в оценке развития моногородов на региональном уровне// Вестник Кемеровского государственного университета. Серия: Политические, социологические и экономические науки. 2018. № 1. С. 128-136. DOI:10.21603/25003372-2018-1-128-136.

К моногородам в России относят населенные пункты, где имеется в наличии предприятие или несколько предприятий, связанных единым производственно-технологическим процессом, объемом производства более $50 \%$ и трудовым потенциалом более 25 \% экономически активного населения. В то же время в понятие «моногород» включается способность организаций и местных жителей самим компенсировать риски внешней экономической среды $[1 ; 2]$. Для получения государственной поддержки моногорода должны иметь комплексный инвестиционный план, направленный на обеспечение устойчивого социально-экономического развития. В практике различных стран можно найти нормативно-правовую базу, обеспечиваю- щую развитие узкоспециализированных территорий, таких как особые экономические зоны, зоны свободной торговли, монопрофильные города. В рамках государственной поддержки на данных территориальных образованиях снижена налоговая нагрузка, проводится диверсификация производства основных отраслей. В России работа федеральных органов власти с узкоспециализированными городами осуществляется по двум направлениям: поддержка городов с особыми условиями хозяйствования (ЗАТО, наукограды); поддержка городов с критическими показателями уровня социально-экономического развития (моногорода). В таблице 1 приведены основные меры поддержки моногородов в России по состоянию на 01.12.2017.

Таблица 1. Перечень основных мер поддержки моногородов в Российской Федерации

Table 1. List of the main supportive measures for monotowns in the Russian Federation

\begin{tabular}{|l|l|}
\hline № & \multicolumn{1}{|c|}{ Наименование меры поддержки моногородов } \\
\hline 1. & Создание территорий опережаюего социально-экономического развития (ТОСЭР) на территориях моногородов \\
\hline 2. & Поддержка субъектов МСП в рамках реализации муниципальных программ развития моногородов \\
\hline 3. & Поддержка инвестиционных проектов, реализуемых на территории моногородов на основе проектного финансирования \\
\hline 4. & Поддержка социально ориентированных некоммерческих организаций \\
\hline 5. & Софинансирование расходов субъектов РФ в целях строительства и реконструкции объектов инфраструктуры \\
\hline 6. & Содействие в подготовке инвестиционных проектов в моногородах \\
\hline
\end{tabular}




\begin{tabular}{|c|c|}
\hline № & Наименование меры поддержки моногородов \\
\hline 7 & Формирование команд, управляющих проектами развития моногородов \\
\hline 8. & Субсидии организациям автомобилестроения на возмещение части затрат на уплату процентов по кредитам \\
\hline 9. & $\begin{array}{l}\text { Субсидии организациям автомобилестроения на перевозку автомобилей, произведенных на территории ДФО, } \\
\text { в другие регионы }\end{array}$ \\
\hline 10. & $\begin{array}{l}\text { Субсидии на возмещение части затрат организациям, ИП, осуществляющим деятельность по обращению с } \\
\text { отходами }\end{array}$ \\
\hline 11. & Субсидии производителям колесных транспортных средств на компенсацию части затрат на содержание рабочих мест \\
\hline 12. & Субсидии российским производителям колесных транспортных средств, расположенных в моногородах \\
\hline 13. & $\begin{array}{l}\text { Субсидии кредитным организациям на возмещение затрат по кредитам физическим лицам на приобретение } \\
\text { автомобилей }\end{array}$ \\
\hline 14 & Субсидии организациям транспортного машиностроения на возмещение части затрат на уплату процентов по кредитам \\
\hline 15 & $\begin{array}{l}\text { Субсидии на закупку автобусов и техники для жилищно-коммунального хозяйства, работающих на газомотор- } \\
\text { ном топливе }\end{array}$ \\
\hline 16 & Субсидии на закупку троллейбусов и трамвайных вагонов \\
\hline 17 & Субсидирование затрат на проведение НИОКТР в рамках реализации КИПов \\
\hline 18 & Субсидия ФГАУ «Российский фонд технологического развития» на цели реализации проектов в области станкостроения \\
\hline 19 & $\begin{array}{l}\text { Субсидии организациям легкой и текстильной промышленности на возмещение части затрат на уплату процен- } \\
\text { тов по кредитам }\end{array}$ \\
\hline 20 & Субсидии организациям народных художественных промыслов на поддержку производства и реализации изделий \\
\hline 21 & $\begin{array}{l}\text { Субсидия из федерального бюджета управляющим организациям индустриальных парков по производству дет- } \\
\text { ских товаров }\end{array}$ \\
\hline 22 & $\begin{array}{l}\text { Субсидия из федерального бюджета организациям на компенсацию части затрат на проведение НИОКТР в } \\
\text { рамках КИПов }\end{array}$ \\
\hline 23 & $\begin{array}{l}\text { Субсидии организациям на компенсацию процентных ставок по кредитам по производству редких и редкозе- } \\
\text { мельных металлов }\end{array}$ \\
\hline 24 & Субсидии организациям лесопромышленного комплекса на возмещение части затрат на обслуживание кредитов \\
\hline 25 & Субсидии предприятиям химического комплекса на возмещение части затрат на уплату процентов по кредитам \\
\hline 26 & Субсидии на поддержку развития производства композиционных материалов (композитов) \\
\hline 27 & Субсидии организациям на компенсацию части затрат на реализацию проектов в области инжиниринга и дизайна \\
\hline 28 & Субсидии на возмещение затрат по созданию инфраструктуры индустриальных парков или технопарков \\
\hline 29 & $\begin{array}{l}\text { Субсидии участникам промышленных кластеров на возмещение части затрат при реализации проектов по им- } \\
\text { портозамещению }\end{array}$ \\
\hline 30 & $\begin{array}{l}\text { Субсидии на софинансирование расходов по возмещению части затрат инвестиционных проектов промышлен- } \\
\text { ных предприятий }\end{array}$ \\
\hline 31 & $\begin{array}{l}\text { Субсидии организациям на компенсацию части затрат, понесенных при реализации проектов по лекарственным } \\
\text { средствам }\end{array}$ \\
\hline 32 & $\begin{array}{l}\text { Реализация мероприятий в сфере занятости населения, направленных на снижение напряженности на рынке } \\
\text { труда моногородов }\end{array}$ \\
\hline 33 & $\begin{array}{l}\text { Субсидия из федерального бюджета субъектам Федерации на поддержку сельскохозяйственных потребитель- } \\
\text { ских кооперативов }\end{array}$ \\
\hline 34 & Государственная поддержка инвестиционных проектов, планируемых к реализации на территории Дальнего Востока \\
\hline 35 & $\begin{array}{l}\text { Модернизация систем коммунальной инфраструктуры через предоставление регионам финансовых средств на } \\
\text { субсидирование кредитов }\end{array}$ \\
\hline 36 & Поддержка субъектов Федерации, реализующих проекты по созданию индустриальных парков и технопарков \\
\hline 37 & Создание и реконструкция объектов культурного наследия и туристской инфраструктуры в моногородах \\
\hline 38 & Гарантийная поддержка субъектов МСП, зарегистрированных в моногородах \\
\hline 39 & Внедрение во всех моногородах успешных практик, включенных в Атлас муниципальных практик \\
\hline 40 & $\begin{array}{l}\text { Размещение информации об инвестиционных возможностях моногородов на Инвестиционном портале регио- } \\
\text { нов России }\end{array}$ \\
\hline 41 & Реализация инвестиционных проектов, направленных на развитие моногородов \\
\hline 42 & Кредитный продукт «МСП - Регион» \\
\hline & \\
\hline
\end{tabular}


Генеральной линией по реабилитации российских моногородов является повышение степени их диверсификации, привлечение инвестиций, повышение активности предпринимателей. Моногорода в силу своей высокой доли в экономике страны и возможности реализации инвестиционных проектов являются научной и практической площадкой для исследования. Поддержка моногородов осуществляется на разных уровнях управления с инструментарием развития разных секторов экономики [2].

В числе принятых в последнее время мер можно отметить программу льготного кредитования малых и средних предприятий под 6,5\% через систему уполномоченных банков, таких как Банк ВТБ, Сбербанк, Россельхозбанк, Альфа-банк, Банк Интеза, МСП Банк. Кредиты сроком до 10 лет погашения будут выдаваться на ведение бизнеса в сельском хозяйстве, обрабатывающих производствах, строительстве, транспорте и связи, туристской деятельности, здравоохранении и утилизации отходов, а также в сфере общественного питания и бытовых услуг. Предприниматели, которые реализуют проекты в регионах Дальневосточного федерального округа, принимают участие в программе на особых условиях. Ещё одно постановление Правительства РФ от 26 апреля 2017 г. № 494 направлено на создание в моногородах «территорий опережающего развития (ТОР)» [3-5].

Практика реализации государственных программ по развитию экономики моногородов позволяет сделать вывод, что в современных условиях хозяйствования проблемы моногородов успешно решаются, если ключевую позицию занимает региональная власть, поскольку в отличие от федерального центра она лучше знает ситуацию, имеет достаточно полномочий, располагает необходимыми ресурсами.

В то же время без федеральной государственной поддержки трудно представить развитие моногородов. Одним из важных показателей развития моногородов является их устойчивость, которая может оценивается индикатором устойчивого развития (англ. index of sustainable developmen). Целью использования данного критерия является формирование прогноза развития города на основе сложившейся ситуации [6]. В стратегиях моногородов целесообразно увязывать целевые индикаторы и с суммой затрат выделяемых из государственного бюджета и показателями экономического и социального эффекта, которые возможно достигнуть за счёт предполагаемых мер.

В число показателей эффективности комплексных инвестиционных планов по модернизации моногородов (далее КИПММ) должны входить такие показатели как: созданные новых рабочих мест; увеличение налоговых поступлений в бюджет; открытие новых производств.

Для оценки эффективности вложения бюджетных средств можно воспользоваться системой коэффициентов. Коэффициент использования бюджетных средств определяется показателем, отражающим приток инвестиций и прогнозируемой суммой поступления налоговых средств по инвестиционным проектам:

$$
K_{э и \sigma c}=O_{\mu n} \div C_{3 б c}
$$

где $K_{\text {эибс }}-$ коэффициент эффективности использования бюджетных средств;

$O_{н n}$ - сумма ожидаемых налогов от реализации инвестиционных проектов по КИПММ.
$C_{\text {збс }}$ - сумма затраченных бюджетных средств на реализацию КИПММ.

Рассчитать фактический коэффициент эффективности использования бюджетных средств можно по формуле:

$$
K_{\text {фэибс }}=O_{\text {фни }} \div C_{\text {збс }}
$$

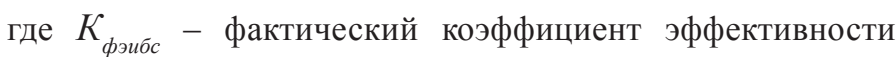
использования бюджетных средств;

$O_{\phi n н}$ - сумма фактически полученных налогов от реализации инвестиционных проектов;

$C_{\text {збс }}$ - сумма затраченных бюджетных средств на реализацию КИПММа.

С помощью метода сравнительного анализа можно сделать выводы об эффективности вложенных средств. Например, коэффициент эффективности использования бюджетных средств на развитие производственной, транспортной и коммунальной инфраструктуры в моногороде должен составлять не менее 0,60 [6].

В Волгоградской области участником приоритетной программы «Комплексное развитие моногородов» является муниципальное образование (далее - МО) Фролово. В МО Фролово через диагностику состояния основных секторов экономики местной властью был разработан Комплексный инвестиционный план развития на период до 2025 г. [7; 8]. В разработке плана модернизации моногорода участвовали все заинтересованные стороны: администрация моногорода, вышестоящие органы власти, руководство градообразующего предприятия, профсоюзы, общественные объединения и население. На основе использования механизма государственно-частного партнерства была построена модель управления и контроля (мониторинга) за реализацией КИПММ. При разработке плана применялись научные методы: синергии, поглощения, синхронизации, кумулятивного эффекта, расчета изменений в финансовых потоках. Цели и задачи КИПММ синхронизировались с федеральными стратегиями и государственными приоритетами, а также со стратегией субъекта Федерации, а результатом выполнения плана должен стать выход МО Фролово на эффективный путь развития.

В городе Фролово проживает более 38 тыс. человек, из них в трудоспособном возрасте находится 23 тыс. человек; градообразующим предприятием является ЗАО «Волга-ФЭСТ», которое осуществляет металлургическое производство и производство готовых металлических изделий.

Результаты диагностики финансового состояния города можно представить в виде матрицы, где аij - платежи контрагентов, где i - номер столбца, j - номер строки (см. таблицу 2).

В каждой ячейке матрицы отражается финансовый поток от одного контрагента к другому. Расчет сальдо для каждого из контрагентов осуществлялся по следующим формулам:

$$
\begin{aligned}
& \text { Сальдо населения }=\sum_{i=1}^{7} a_{i 2}-\sum_{j=1}^{7} a_{2 j} . \\
& \text { Сальдо ОМС }=\sum_{i=1}^{7} a_{i 3}-\sum_{j=1}^{7} a_{3 j} .
\end{aligned}
$$

Сальдо градообразующего предприятия $=\sum_{i=1}^{7} a_{i 4}-\sum_{j=1}^{7} a_{4 j}$.

Сальдо инфраструктуры $=\sum_{i=1}^{7} a_{i 5}-\sum_{j=1}^{7} a_{5 j}$. 
Таблица 2. Матрица финансового состояния моногорода, полученная на основе проведенной диагностики

Table 2. The financial condition matrix of a monotown obtained on the basis of the carried-out diagnostics

\begin{tabular}{|c|c|c|c|c|c|c|c|c|}
\hline \multicolumn{2}{|c|}{} & $\mathbf{i = 1}$ & $\mathbf{i = 2}$ & $\mathbf{i}=\mathbf{3}$ & $\mathbf{i}=\mathbf{4}$ & $\mathbf{i = 5}$ & $\mathbf{i = 6}$ & $\mathbf{i = 7}$ \\
\cline { 3 - 9 } & $\mathbf{B C}$ & Население & ОМС & ГРОП & Инфраструктура & МПМБ & ВОВ \\
\hline $\mathrm{j}=1$ & ВС & & $\mathrm{a}_{21}$ & $\mathrm{a}_{31}$ & $\mathrm{a}_{41}$ & $\mathrm{a}_{51}$ & $\mathrm{a}_{61}$ & \\
\hline $\mathrm{j}=2$ & Население & $\mathrm{a}_{12}$ & & $\mathrm{a}_{32}$ & $\mathrm{a}_{42}$ & $\mathrm{a}_{52}$ & $\mathrm{a}_{62}$ & $\mathrm{a}_{72}$ \\
\hline $\mathrm{j}=3$ & ОМС & $\mathrm{a}_{13}$ & $\mathrm{a}_{23}$ & & $\mathrm{a}_{43}$ & $\mathrm{a}_{53}$ & $\mathrm{a}_{63}$ & $\mathrm{a}_{73}$ \\
\hline $\mathrm{j}=4$ & ГРОП & $\mathrm{a}_{14}$ & $\mathrm{a}_{24}$ & $\mathrm{a}_{34}$ & & $\mathrm{a}_{54}$ & $\mathrm{a}_{64}$ & $\mathrm{a}_{74}$ \\
\hline $\mathrm{j}=5$ & Инфраструктура & $\mathrm{a}_{15}$ & $\mathrm{a}_{25}$ & $\mathrm{a}_{35}$ & $\mathrm{a}_{45}$ & & $\mathrm{a}_{65}$ & $\mathrm{a}_{75}$ \\
\hline $\mathrm{j}=6$ & МПМБ & $\mathrm{a}_{16}$ & $\mathrm{a}_{26}$ & $\mathrm{a}_{36}$ & $\mathrm{a}_{46}$ & $\mathrm{a}_{56}$ & & $\mathrm{a}_{76}$ \\
\hline $\mathrm{j}=7$ & ВОВ & & $\mathrm{a}_{27}$ & $\mathrm{a}_{37}$ & $\mathrm{a}_{47}$ & $\mathrm{a}_{57}$ & $\mathrm{a}_{67}$ & \\
\hline
\end{tabular}

где

ГРОП - градообразующее предприятие;

ОМС - органы местного самоуправления;

Сальдо местной промышленности и малого бизнеса $=\sum_{i=1}^{7} a_{i 6}-\sum_{j=1}^{7} a_{6 j}$

Общее сальдо моногорода рассчитывается как сумма взаимодействий городских контрагентов с внешними контрагентами, т. е. с внешней средой и с вышестоящими органами власти:

Сальдо города $=\sum \sum a_{i j}-\sum \sum a_{i j}=\sum$ Сальдо с контрагентами

На основании расчета сальдо моногорода можно представить и динамику его развития, которая определяется как разность между сальдо моногорода и прогнозируемой амортизацией. Совокупное сальдо внутренних субъектов моногорода (градообразующее предприятие, население, местная промышленность и малый бизнес, органы местного самоуправления и инфраструктура) в 2010 г. имело резкую отрицательную динамику, моногород находился в «критическом положении». В частности, экономика города
ВОВ - вышестоящие органы власти;

ВС- внешняя среда;

МПМБ - местная промышленность и малый бизнес - МБ.

производила недостаточно товаров и услуг для внешней среды, продукция местных предприятий и МСП потреблялась на месте, внутренние ресурсы не обеспечивали модернизацию объектов жилищно-коммунальной и транспортной инфраструктуры. Устранить накопившиеся проблемы в инфраструктуре моногорода можно было на основе разработки КИПММа [9; 10]. В зависимости от сочетания величины сальдо моногорода и динамики его изменений, состояние моногорода можно определить как «критическое», «тяжелое», либо «стабильное». В 2010 г. город находился на поле «состояние критическое» и стратегия была «выживание». К 2017 г. в экономике города произошли определенные положительные изменения (построен завод по сушке овощей, идет реконструкция ЖКХ, строительство дорог), город переместился на поле - «стабильное положение», а стратегия стала «концентрация сил к бою».

На рисунке 1 представлена матрица диагностики состояния и стратегий моногорода Фролова.

С помощью методов экономико-математического моделирования можно рассчитать структуру и параметры

\begin{tabular}{|c|c|c|c|c|}
\hline & & \multicolumn{3}{|c|}{ Динамика сальдо моногорода } \\
\hline & & отрицательная & нулевая & положительная \\
\hline \multirow{3}{*}{ 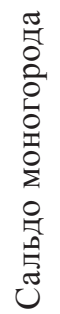 } & отрицательное & $\begin{array}{l}\text { Критическое } \\
\text { состояние }\end{array}$ & $\begin{array}{l}\text { Относительно критическое } \\
\text { состояние }\end{array}$ & Тяжелая ситуация \\
\hline & нулевое & $\begin{array}{l}\text { Относительно } \\
\text { критическое состояние }\end{array}$ & Тяжелая ситуация & $\begin{array}{l}\text { Стабильное } \\
\text { состояние }\end{array}$ \\
\hline & положительное & Тяжелая ситуация & Стабильное состояние & $\begin{array}{l}\text { Динамически изменяющееся } \\
\text { положительное состояние }\end{array}$ \\
\hline
\end{tabular}

Рис. 1. Матрица стратегий развития моногорода Фролово, Волгоградская область

Fig. 1. Matrix of development strategies of the monotown of Frolovo, Volgograd Region 
В таблице 3 представлены основные инвестиционные проекты, которые вошли в КИПММ.

Таблица 3. Основные инвестиционные проекты КИПММ г. Фролово Волгоградской области Table 3. The main investment projects in the monotown of Frolovo, Volgograd Region

\begin{tabular}{|c|c|}
\hline Название проекта & Результат \\
\hline $\begin{array}{l}\text { Модернизация ЗАО «Фроловский электросталеплавильный } \\
\text { завод»: Производство сортового и фасонного проката в } \\
\text { объеме } 450-500 \text { тыс. т } \\
\text { Сметная стоимость - 4674,6 млн руб. } \\
\text { Источник финансирования: } \\
2 \text { \% - федеральный бюджет* } \\
98 \text { \% - собственные средства ЗАО «Волга-ФЭСТ» }\end{array}$ & $\begin{array}{l}\text { Создание на ЗАО «Волга-ФЭСТ» прокатного производ- } \\
\text { ства позволит перейти на качественно новый уровень } \\
\text { его развития: из завода по производству полуфабриката } \\
\text { превратиться в завод, производящий продукцию более } \\
\text { глубокой степени переработки (арматура, гладкий и фа- } \\
\text { сонный сортовой прокат) с дополнительно добавленной } \\
\text { стоимостью, более широким спектром возможностей. } \\
\text { Будет создано дополнительно } 350 \text { рабочих мест }\end{array}$ \\
\hline $\begin{array}{l}\text { Реконструкция ЖБИ с переводом его в комбинат по строи- } \\
\text { тельству домов на основе безригельного каркаса } \\
\text { Сметная стоимость - 900,0 млн руб. } \\
\text { Источник финансирования: } \\
11,96 \text { \% - федеральный бюджет* } \\
\text { 51,45 \% - привлеченные средства } \\
\text { 36,59 \% - собственные средства }\end{array}$ & $\begin{array}{l}\text { Реализация проекта позволит создать } 400 \text { новых рабо- } \\
\text { чих мест; расширить жилой фонд городского округа } \\
\text { г. Фролово; стимулировать внедрение инновационных } \\
\text { технологий; снизить себестоимость строительных мате- } \\
\text { риалов и конструкций }\end{array}$ \\
\hline $\begin{array}{l}\text { Создание молодежного инновационного кластера } \\
\text { Сметная стоимость - 213,8 млн руб. } \\
\text { Источник финансирования: } \\
20,0 \text { \% - федеральный бюджет } \\
\text { 20,0 \% - областной бюджет } \\
\text { 10,0 \% - местный бюджет } \\
\text { 50,0 \% - средства инвесторов }\end{array}$ & $\begin{array}{l}\text { Реализация проекта приведет к увеличению числа субъ- } \\
\text { ектов малого предпринимательства; среднесписочной } \\
\text { численности работников малых предприятий; созданию } \\
90 \text { новых рабочих мест; увеличению занятости молоде- } \\
\text { жи с использованием интернет-возможностей }\end{array}$ \\
\hline $\begin{array}{l}\text { Строительство бассейна для оздоровительного плавания } \\
\text { Сметная стоимость - 72,0 млн руб. } \\
\text { Источник финансирования: } \\
\text { 30,0 \% - федеральный бюджет; } \\
\text { 45,0 \% - областной бюджет; } \\
\text { 25,0 \% - муниципальный бюджет }\end{array}$ & $\begin{array}{l}\text { Создание } 16 \text { новых рабочих мест; привлечение к ре- } \\
\text { гулярным занятиям физкультурой и спортом } 4,0 \text { тыс. } \\
\text { человек, в том числе - } 2,0 \text { тыс. детей; улучшение общей } \\
\text { спортивно-оздоровительной обстановки в городе, рас- } \\
\text { пространение здорового образа жизни }\end{array}$ \\
\hline $\begin{array}{l}\text { Реконструкция очистных сооружений } \\
\text { Сметная стоимость - 225,0 млн руб. } \\
\text { Стоимость проектирования - 7,5 млн руб. } \\
\text { Источник финансирования: } \\
\text { 75,0 \% - областной бюджет } \\
\text { 25,0 \% - муниципальный бюджет }\end{array}$ & $\begin{array}{l}\text { Ввод в действие современного комплекса очистных } \\
\text { сооружений производительностью } 18000 \text { м³/сут; сниже- } \\
\text { ние уровня загрязнения окружающей среды, снижение } \\
\text { уровня заболеваемости, повышение качества жизни } \\
\text { населения; создание } 12 \text { рабочих мест }\end{array}$ \\
\hline $\begin{array}{l}\text { Строительство детского сада на } 120 \text { мест } \\
\text { Сметная стоимость - 140,00 млн руб. } \\
\text { Источник финансирования: } \\
75 \text { \% - областной бюджет } \\
25 \text { \% - муниципальный бюджет }\end{array}$ & $\begin{array}{l}\text { Введение в строй детского дошкольного учреждения на } \\
120 \text { мест, ликвидация дефицита мест в детских дошколь- } \\
\text { ных учреждениях; создание } 35 \text { постоянных рабочих } \\
\text { мест, } 30 \text { временных рабочих мест; сокращение очереди } \\
\text { на получение мест в детсадах }\end{array}$ \\
\hline $\begin{array}{l}\text { Подготовка инвестиционных площадок } \\
\text { Сметная стоимость - 57,4 млн руб. } \\
\text { Источник финансирования: } \\
\text { 50,0 \% - федеральный бюджет } \\
40,0 \text { \% - областной бюджет } \\
\text { 10,0 \% - бюджет МО }\end{array}$ & $\begin{array}{l}\text { Снятие инфраструктурных ограничений, повышение } \\
\text { инвестиционной привлекательности моногорода }\end{array}$ \\
\hline
\end{tabular}




\begin{tabular}{|l|l|}
\hline \multicolumn{1}{|c|}{ Название проекта } & \multicolumn{1}{|c|}{ Результат } \\
\hline Строительство завода по производству стеклянной тары & Организация производства стеклотары, объемом 210 млн \\
Сметная стоимость - 1204,7 млн руб. & шт. условных единиц в год; создание 352 новых постоян- \\
Источник финансирования: & ных рабочих мест. \\
$17,5 \%-$ федеральный бюджет & \\
$82,5 \%-$ средства инвестора & \\
\hline
\end{tabular}

городской экономики. Для этого в моногороде с помощью математических моделей Солоу, Форестера, динамических рядов выделяют несколько групп организаций (предприятий): материальную, фондосоздающую и потребительскую. В соответствии с проведенной группировкой строится модель функционирования основных секторов экономики моногорода, которая представлена на рисунке 2.

При построении данной модели за каждой группой организаций (предприятий) закреплялись основные производственные фонды; учитывались трудовые ресурсы, инвестиции, которые могли свободно перемещаться между ними. Производственные возможности каждой группы организаций задавались в виде линейно-однородных производственных функций:

$$
X_{i}=F_{i}\left(K_{i}, L_{i}\right), i=0,1,2 \text {, }
$$

где $X, K_{i}, L, I_{i}$ - соответственно выпуск продукции, основные производственные фонды, число занятых в і-ой группе предприятий, инвестиции в і-ю группу предприятий.

При построении математической модели применялись следующие ключевые допущения:

1. В данном временном периоде технологический уклад не менялся (1).

2. Трудовые ресурсы предприятий $-L$ изменялись в соответствии с ростом производства $-V$.

3. Лаг капиталовложений отсутствовал.

4. Коэффициенты износа основных производственных фондов $-\mu_{i}$ и прямых материальных затрат $-\alpha_{i}$ групп организаций являются условно постоянными.

5 . Время - $t$ изменялось непрерывно.

Полученная в ходе исследования, экономико-математическая модель экономики моногорода с учетом состояния его инфраструктуры описывалось следующей системой дифференциальных и балансовых уравнений:

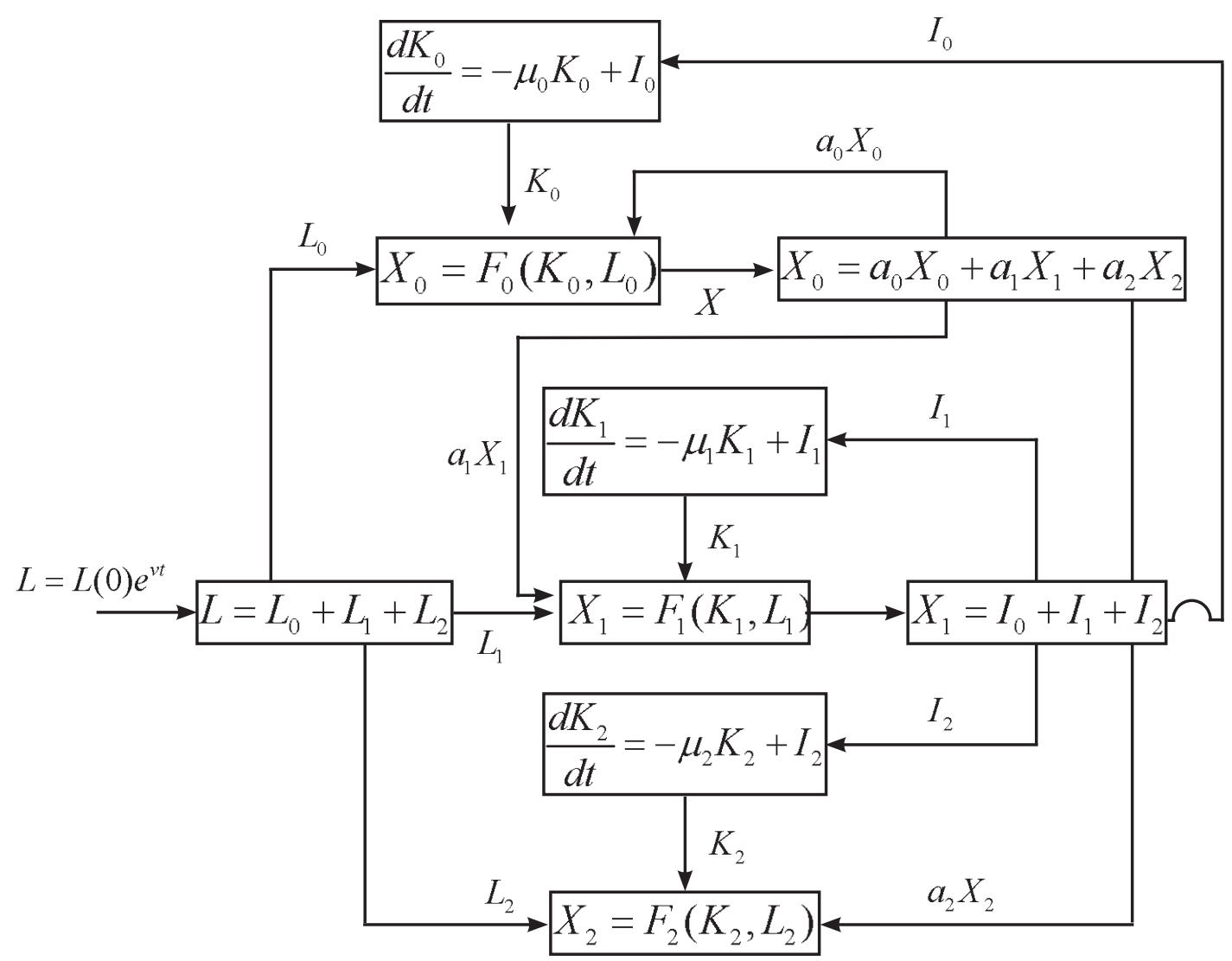

Рис. 2. Структурная схема взаимодействия материальных и финансовых потоков и трудовых ресурсов в экономике моногорода Fig. 2. Block diagram showing the interaction between material and financial flows and manpower in monotown economy 


$$
\left\{\begin{array}{l}
L=L_{0} e^{v t} \\
L=L_{0}+L_{1}+L_{2}, \\
\frac{d K_{i}}{d t}=-\mu_{i} K_{i}+I_{i}, \\
X_{1}=I_{0}+I_{1}+I_{2}=I \\
X_{0}=a_{0} X_{0}+a_{1} X_{1}+a_{2} X_{2} .
\end{array}\right.
$$

Преобразования при реализации методики численного исследования динамики осуществлялись по следующему циклу:

$$
L=L_{0}+L_{1}+L_{2} \Rightarrow 1=\Theta_{0}+\Theta_{1}+\Theta_{2}
$$

где $\Theta_{i}=\frac{L_{i}}{L}$ - доля числа занятых в $i$-ой группе предприятий.

$I=I_{0}+I_{1}+I_{2} \Rightarrow 1=S_{0}+S_{1}+S_{2}$

$S_{i}=\frac{I_{i}}{I}-$ доля инвестиций в $i$-ю группу предприятий.

$$
\begin{aligned}
& X_{0}=a_{0} X_{0}+a_{1} X_{1}+a_{2} X_{2} \Rightarrow \frac{\left(1-a_{0}\right) X_{0} L_{0}}{L L_{0}}=\frac{a_{1} X_{1} L_{1}}{L L_{1}}+\frac{a_{2} X_{2} L_{2}}{L L_{2}} \Rightarrow \\
& \left(1-a_{0}\right) \Theta_{0} f_{0}\left(k_{0}\right)=a_{1} \Theta_{1} f_{1}\left(k_{1}\right)+a_{2} \Theta_{2} f_{2}\left(k_{2}\right) \\
& f_{i}\left(k_{i}\right)=\frac{X_{i}}{L_{i}} \text {-производительность труда в } i \text {-й группе. }
\end{aligned}
$$

В безразмерных относительных показателях модель представлена в следующей форме:

$$
\left\{\begin{array}{l}
\Theta_{0}+\Theta_{1}+\Theta_{2}=1, \\
S_{0}+S_{1}+S_{2}=1, \\
\frac{d k_{i}}{d t}=\left(\frac{\Theta_{1} S_{i}}{\Theta_{i}}\right) f_{1}\left(k_{1}\right)-\mu_{i} k_{i}, \quad k_{i}(0)=k_{i 0}, k_{i}=\frac{K_{i}}{L_{i}}, \\
\left(1-a_{0}\right) \Theta_{0} f_{0}\left(k_{0}\right)=a_{1} \Theta_{1} f_{1}\left(k_{1}\right)+a_{2} \Theta_{2} f_{2}\left(k_{2}\right) .
\end{array}\right.
$$

Для нахождения оптимального распределения инвестиций между группами организаций была сформулирована задача, которая имела следующий вид:

$$
\begin{gathered}
\Theta_{1}^{\alpha_{2}} \Theta_{2}^{1-\alpha_{2}} S_{1}^{\left(\alpha_{1} \alpha_{2}\right) /\left(1-\alpha_{1}\right)} S_{2}^{\alpha_{2}} \rightarrow \max \\
\left\{\begin{array}{l}
\Theta_{0}+\Theta_{1}+\Theta_{2}=1 \\
S_{0}+S_{1}+S_{2}=1 \\
\Theta_{i}, S_{i} \geq 0
\end{array}\right.
\end{gathered}
$$

Последняя система представляла собой ограничения, учитываемые при реализации процедуры оптимизации. Производственные функции принимались в формуле Кобба-Дугласа согласно зависимости: 


$$
X_{i}=F_{i}\left(K_{i}, L_{i}\right)=A_{i} K_{i}^{\alpha_{i}} L_{i}^{1-\alpha_{i}}(i=0,1,2) \text {, }
$$

где $A_{i}$ - параметры производственной функции, числовые значения которых определяются на основе статистических данных с помощью метода наименьших квадратов (МНК). Численные расчеты по полученной модели производились в среде MathCad 14 на ПЭВМ. Результаты параметризации зависимости (8) по МНК составили:

- для материальной группы предприятий: $X_{0}=494,54 K_{0}$ $0,73 L_{0} 0,27$.

- для фондосоздающей группы предприятий: $X_{1}=$ $932,6 K_{1} 0,22 L_{1} 0,78$.
- для потребительской группы предприятий: $X_{2}=827,7 K_{2}$ $0,29 L_{2} 0,71$.

По результатам проведенных исследований установлено, что наибольший эффект от инвестиций будет достигнут, если в материальную группу предприятий будет направлено 22 \% инвестиций, в фондосоздающую - 57 \%, а в потребительскую - 21 \% [11; 12]. Данное распределение инвестиционных потоков позволяет увеличить темпы роста городского продукта до 6,3 \%. Эффективность распределения инвестиций сказывается на экономическом росте, развитии социально-экономической сферы моногородов [13].

\title{
Литература
}

1. Медведева Л. Н., Старовойтова Я. М. Стратегии развития российских городов // Горизонты экономики. 2013. № 2. С. 89-95.

2. Об утверждении перечня монопрофильных муниципальных образований Российской Федерации (моногородов). Распоряжение Правительства Российской Федерации от 29.07.2014 № 1398-р // Новости регионов. Режим доступа: http://regnews.org/doc/aq/pm.htm (дата обращения: 30.01.2018).

3. Об особенностях создания территорий опережающего социально-экономического развития на территориях монопрофильных муниципальных образований Российской Федерации (моногородов). Постановление Правительства Российской Федерации от 22 июня 2015 года № 614 (ред. от 26.04.2017) // Законы, кодексы и нормативно-правовые акты Российской Федерации. Режим доступа: http://legalacts.ru/doc/postanovlenie-pravitelstva-rf-ot-22062015-n-614/ (дата обращения: 30.01.2018).

4. О территориях опережающего социально-экономического развития в Российской Федерации. Федеральный закон от 29.12.2014 г. № 473-ФЗ // Президент России. Режим доступа: http://www.kremlin.ru/acts/bank/39279 (дата обращения: 02.02.2018).

5. Моногорода РФ: сайт. Режим доступа: http://моногорода.рф (дата обращения: 25.01.2018).

6. Indicators of Sustainable Development // Environmental Software and Services. Режим доступа: http://www.ess.co.at/ GAIA/Reports/indics.html (дата обращения: 04.09.2016).

7. Волгоградская область: сайт Администрации Волгоградской области. Режим доступа: http://www.volgograd.ru (дата обращения: 26.01.2018).

8. Администрация городского округа города Фролово: сайт. Режим доступа: http://frolovoadmin.ru (дата обращения: 26.01.2018).

9. Колемаев В. А. Математическая экономика. М.: ЮНИТИ, 1998. 240 с.

10. Кузнецов Н. Г., Богданов С. И., Карева Н. В. Методическое руководство по составлению и анализу математических моделей производственно-экономических систем на базе макроэкономических показателей. Волгоград: Волгогр. гос. с.-х. акад., 2008. 98 с.

11. Медведева Л. Н., Рогачев А. Ф. Формирование промышленно-инвестиционной политики в среднем городе на основе методов экономико-математического моделирования: препринт. Волгоград: Изд-во Волгоградского гос. ун-та, 2012.15 с.

12. Рогачев А. Ф., Шохнех А. В., Медведева Л. Н. Экономико-математическое моделирование управления развитием средних и моногородов с использованием когнитивных карт // Аудит и финансовый анализ. 2017. № 2. С. $122-124$.

13. Медведева Л. Н., Козенко К. Ю., Комарова О. П. Концепт-стратегия «зеленых городов» на базе промышленно развитых средних городов. Волгоград: Крутон, 2015. 256 с.

\section{KEY INDICATORS IN DEVELOPMENT ASSESSMENT OF MONOTOWNS AT THE REGIONAL LEVEL Liudmila N. Medvedeval, ${ }^{1,}$ Mikhail K. Starovoitov ${ }^{1}$, Elena V. Goncharova ${ }^{1}$, Iuliia I. Gushchina ${ }^{1}$}

\author{
${ }^{1}$ Volzhsky Polytechnic Institute (branch) of Volgograd State Technical University, 42a, Engels St., Volzhsky, Russia, 404121 \\ @ milena.medvedeva2012@yandex.ru
}

Received 19.02.2018. Accepted 12.03.2018.

Keywords: monocities, investments, instrumentation, budgetary efficiency, city economy, economymathematical model.
Abstract: The development of single-industry cities, whose economy once depended entirely on one or two city-forming enterprises and local research institutes and design bureaus, is extremely relevant. A government commission has adopted integrated investment plans for the modernization of single-industry towns; it has given permission to create «Free Economic Zones» and «territories for advanced development» on their basis, which should influence their economic growth. The current analysis has shown that 1) the main focus of the mono- 
city development strategy is on the development of local industry and small business related to the defense complex or agriculture; 2) local authorities propose projects for the construction of pig farms, milk, meat, oil, fish processing industries, or opening new construction industry enterprises. However, the issue of effective investment of budget funds continues to remain highly debated in economics. The paper features some key indicators of the development of single-industry towns, as well as economic-mathematical models of distribution of investment flows, which make it possible to predict the vectors of their long term development.

For citation: Medvedeva L. N., Starovoitov M. K., Goncharova E. V., Gushchina Iu. I. Ispol'zovanie kliuchevykh pokazatelei v otsenke razvitiia monogorodov na regional'nom urovne [Key Indicators in Development Assessment of Monotowns at the Regional Level]. Bulletin of Kemerovo State University. Series: Political, Sociological and Economic Sciences, no. 1 (2018): 128-136. DOI:10.21603/2500-3372-2018-1-128-136.

\section{References}

1. Medvedeva L. N., Starovoitova Ia. M. Strategii razvitiia rossiiskikh gorodov [Strategies of development for the Russian cities]. Gorizonty ekonomiki = Horizons of econonics, no. 2 (2013): 89-95.

2. Ob utverzhdenii perechnia monoprofil'nykh munitsipal'nykh obrazovanii Rossiiskoi Federatsii (monogorodov) [About the approval of the list of monoprofile municipal units of the Russian Federation (monotowns)]. Order of the Government of the Russian Federation 29.07.2014 No. 1398-p. Available at: http://regnews.org/doc/aq/pm.htm (accessed 30.01.2018).

3. Ob osobennostiakh sozdaniia territorii operezhaiushchego sotsial'no-ekonomicheskogo razvitiia na territoriiakh monoprofil'nykh munitsipal'nykh obrazovanii Rossiiskoi Federatsii (monogorodov) [Features of creation of territories of the advancing social and economic development in monoprofile municipal units of the Russian Federation (monotowns)]. Decree of the Government of the Russian Federation of June 22, 2015 No. 614 (ed. 26.04.2017). Available at: http://legalacts.ru/doc/ postanovlenie-pravitelstva-rf-ot-22062015-n-614/ (accessed 30.01.2018).

4. O territoriiakh operezhaiushchego sotsial'no-ekonomicheskogo razvitiia v Rossiiskoi Federatsii [Territories of the advancing social and economic development in the Russian Federation]. Federal law from 29.12.2014 No. 473-FZ. Available at: http://www.kremlin.ru/acts/bank/39279 (accessed 02.02.2018).

5. Monogoroda RF [Monotowns of the Russian Federation]. Available at: http://моногорода.pф (accessed 25.01.2018).

6. Indicators of Sustainable Development. Available at: http://www.ess.co.at/GAIA/Reports/indics.html (accessed 04.09.2016).

7. Volgogradskaia oblast'[Volgograd region]. Available at: http://www.volgograd.ru (accessed 26.01.2018).

8. Administratsiia gorodskogo okruga goroda Frolovo [Administration of the city district of the city of Frolovo]. Available at: http://frolovoadmin.ru (accessed 26.01.2018).

9. Kolemaev V. A. Matematicheskaia ekonomika [Mathematical economics]. Moscow: IuNITI, 1998, 240.

10. Kuznetsov N. G., Bogdanov S. I., Kareva N. V. Metodicheskoe rukovodstvo po sostavleniiu i analizu matematicheskikh modelei proizvodstvenno-ekonomicheskikh sistem na baze makroekonomicheskikh pokazatelei [The methodical guide to drawing up and the analysis of mathematical models of productive and economic systems on the basis of macroeconomic indicators]. Volgograd: Volgogr. gos. s.-kh. akad., 2008, 98.

11. Medvedeva L. N., Rogachev A. F. Formirovanie promyshlenno-investitsionnoi politiki v srednem gorode na osnove metodov ekonomiko-matematicheskogo modelirovaniia: preprint [The formation of industrial investment policy in the average city on the basis of methods of economic-mathematical modeling: preprint]. Volgograd: Izd-vo Volgogradskogo gos. un-ta, 2012, 15.

12. Rogachev A. F., Shokhnekh A. V., Medvedeva L. N. Ekonomiko-matematicheskoe modelirovanie upravleniia razvitiem srednikh i monogorodov s ispol'zovaniem kognitivnykh kart [Economic-mathematical modeling of management of development of averages and monotowns with use of cognitive maps]. Audit $i$ finansovyi analiz $=$ Audit and Financial Analysis, no. 2 (2017): $122-124$.

13. Medvedeva L. N., Kozenko K. Iu., Komarova O. P. Kontsept-strategiia «zelenykh gorodov» na baze promyshlenno razvitykh srednikh gorodov [Concept strategy of «the green cities» on the basis of industrially developed average cities]. Volgograd: Kruton, 2015, 256. 